\title{
Acehnese People's Information Seeking Behavior about COVID-19
}

\author{
http://dx.doi.org/10.25008/jkiski.v6i1.482
}

\author{
Rizanna Rosemary ${ }^{1 *}$, Hamdani M. Syam ${ }^{2}$, Nur Anisah ${ }^{3}$, Deni Yanuar ${ }^{4}$, \\ Heru Syah Putra ${ }^{5}$ \\ ${ }^{1,2,3,4}$ Department of Communication Studies, Universitas Syiah Kuala \\ Jl. Tanoh Abee Darussalam, Banda Aceh 23111 - Indonesia \\ ${ }^{5}$ National Institute for Public Administration \\ Jl. DR. Mr. Teuku Haji Muhammad Hasan, Darul Imarah, Aceh Besar 23352 - Indonesia \\ *Corresponding author: rizanna.rosemary@unsyiah.ac.id
}

Submitted: March 18, 2021, Revised: April 22, 2021, Accepted: June 12, 2021

Accredited by Kemristekdikti No. 28/E/KPT/2019

\begin{abstract}
This research aims to identify types of media used by the Acehnese people in seeking information about COVID-19, and people's perceptions and responses to the information that increases their likelihood of the risk of the pandemic. This study employs a quantitative approach, in which an online survey distributed through social media. All 324 respondents gave their consent to participate in filling out the research questionnaire. The study found that Acehnese people prefer online media and television (TV) to receive information about COVID-19, especially when people can access the information online (streaming). The finding indicates that people tend to trust information obtained through the media more than direct information (face to face) conveyed by the government. Regarding the public responses, this study found that most respondents argue the lack of government action in disseminating information about COVID-19. It is believed that this condition is likely to bring up false information (hoax) from untrustworthy information sources. This response has an impact on the level of public trust towards the government as the main source of information in handling the pandemic. Respondents claim that the local government has a slow response in providing information about people who are infected by the virus, including insufficient information on the intervention of prevention and treatment carried out to stop the spread of the virus.
\end{abstract}

Keywords: COVID-19; hoax; information seeking; media; response

\section{Introduction}

The COVID-19 pandemic has global, regional, national, and local impacts. The first case of COVID-19 in Aceh occurred on March 23, 2020. A patient from Lhokseumawe City died after being tested positive for COVID-19 and became Patient Under Supervision (PDP). Therefore, on March 26, 2020, the spokesperson of Aceh COVID-19 Task Force 2020 announced that it was the first case in Aceh or so-called 826 cases for national level. At the beginning of the COVID-19 outbreak in
Aceh, the local Government received a positive acknowledgement from the central government. The government considers Aceh as one of the Provinces to well-perform in reducing the spread of Coronavirus, with only a small number of positive cases found compared to other provinces in the country (Eda, 2020) However, towards the middle of the year, particularly, after the celebration of two Islamic Religious Holidays - Eid al-Fitr and Eid alAdha, the COVID-19 cases in Aceh increased significantly (Bakri, 2020). Even on August 17, 
2020, the Province ranks third for the highest number of cases found daily, after Jakarta and East Java (Dinamika, 2020). As of this writing, December 9, 2020, the Aceh Government Health Service has identified 8444 confirmed positive cases of COVID-19, 1093 are in treatment, and 325 people have died (Aceh Health Department, 2020)

Several efforts have been carried out by the local and central government to stop the spread of COVID-19 throughout Indonesia. The government has declared the country to be in a state of a health emergency, resulting in the closure of campuses, schools, houses of worship, tourist areas, and other public spaces. Moreover, activities involving large gatherings of people are prohibited and people are advised to avoid crowds. The government urged people to stay and continue their activities from home during the pandemic. For this reason, all community activities are carried out online. The Aceh government also made several efforts to stop the spread of the virus. As stated by the acting Governor of Aceh (Now Governor) Nova Iriansyah, namely (1) establishing an information center, setting up hospitals with isolation rooms for patients infected by COVID-19, (2) educating the public of the spread of COVID-19, (3) imposing night restriction, and (4) building an alert system task force coordinated by the city and district health office to identify the spread of COVID-19 (Supriatin, 2020).

This pandemic has impacted the lives of the Acehnese people. Many companies, public transportation, and tourism sites were called for a temporary closure. Moreover, offices are required to reduce their working hours, resulting in people earning less income and even losing jobs. This has significantly affected the economics of the community (Ngadi, Meliana, \& Purba, 2020). However, the impact of COVID-19 includes both physical and psychological, for example, stress and depression among patients and the community in general. Patients are anxious when diagnosed or confirmed positive and infected by the virus and worried that they will be stigmatized by the public. The public is also worried about the increasing numbers of COVID-19 cases. Meanwhile, the media plays an important role in disseminating both accurate and false information (hoaxes). This condition increases stress and has an impact on lowering people's immune systems (Afifah, Nur, 2020).

Despite the significant impact of COVID19, many people, including the Acehnese people have different perceptions and responses to respond to this global pandemic, ranging from those who believe to those disbelieve the threats and effects of COVID-19. For instance, within a communal community, like the Acehnese people, who are used to carry out collective gatherings and group activities, the policy to stay at home during COVID-19 limits the movement of the community in carrying out their daily social activities outside their home. The unprecedented condition has changed the patterns of how the community interacts and communicates. For example, shaking hands and hugging people when meeting was considered normal; but during the pandemic, the social interaction pattern changes, and influences people's behavior with one another.

Interaction and communication patterns have also been replaced through online media, such as WhatsApp, Skype, Zoom, Google Meet, and other applications. These online platforms are used for searching and exchanging information, in the context of working relations or for the purpose to stay in touch with each other (Budiansyah, 2020). Although the changes in the way people carry out personal and social activities have shifted by the existence of technology, in general, people still carry out normal activities collectively and tend to ignore the recommended health protocols, that is the '3M Campaign'-memakai masker (wearing mask), menjaga jarak (physical and social distancing), and mencuci tangan (washing hands).

The ways of how society differs in response to COVID-19 information are influenced not only by the socio-cultural factors practiced in the community but also by how people seek information that is needed and considered important. The search for information by a person or society is influenced by the media they used or utilized in finding the information (information-seeking behavior) (Kim, Ahn, Atkinson, \& Kahlor, 2020; Rosemary, 2018).

The level of frequency of people using the media indicates the type of media used for information seeking (Atkin, 1972; Joanna, Ching-Sei, I-Tien, \& Sun-Kyung, 2014; Kim, Sun, Sin, Joanna, Ching, \& He, 2013; Muusses, Weert, van, \& Dulmen, van, 2011). If a person frequently uses social media, such as Facebook, Twitter, and Instagram, then it is likely the person is looking for the information about COVID-19 through social media. According to Wilson (1999), information behavior relates to how a person identifies his need of the 
information and the effort in searching for information through various ways. Wilson (1999), further explains that information behavior involves human behavior using information through various sources and channels of information (both passive and active information seeking). People tend to search for information that is related to their daily needs and utilize the media they trust.

Recent studies showed an increase in people's behavior in seeking information about COVID-19 in Indonesia, especially since the end of January 2020. This quantitative study in which the data collected through the Google Trends application found that the Indonesian Government's statement regarding COVID-19 was the factor driving the increase and the shift of people's information seeking activities about the Coronavirus outbreak (Limilia \& Pratamawaty, Bona, 2020)

The rise of information seeking activities is argued to affect changes in people's perceptions and behaviors in response to COVID-19 pandemic. However, with the significant increase in the number of COVID-19 cases in Indonesia, including in Aceh Province, it seems to be intriguing to identify how the Acehnese people searched for information about COVID19 and their responses to the messages. This study aims to answer the following research questions: (1) to identify the media used in seeking information, and (2) to investigate how the public's perceptions and responses to the COVID-19 information they are seeking or receiving.

\section{Theoretical Framework}

During the unprecedented COVID-19 pandemic, the government requires to carry out effective risk communication. Poor risk communication can lead to an increase in confusion and uncertainty in society. According to Abrams and Matthew (2020) risk communication aims to make the public calm and reduce the risks posed by a global health outbreak that has a systemic impact, like COVID-19 (Abrams, M \& Matthew, 2020). Meanwhile Frewer (2004) argues that risk communication must consider the values and concerns of the communities. When people need information containing high-risk consequences, such as a disease or a pandemic, they prefer clear and sufficient information about the risk. With the efficacy information about the risk, people and the community are expected to carry out risk mitigation as needed by the information given (Covello, T, Peters, G,
Wojtecki, G, \& Hyde, C, 2001; Evensen \& Clarke, 2012; Feldman, Hart, Sol, \& Milosevic, 2015; Rosemary \& Evensen, 2020).

However, how one views the risk of an outbreak does not always correlate with the actual risk. For example, the increasing number of COVID-19 cases in Aceh Province has made people aware of the dangers of the virus. People consider the pandemic to be negative for health, welfare, and their livelihoods. Yet, the positive public understanding of the outbreak is not in line with their adherence to the health protocols to prevent the spread of COVID-19. This nonlinear condition is influenced by two factors: differences in the socio-cultural context of the local community (Lewis \& Lewis, 2014), and the process of seeking information about COVID-19 by the community (Kim et al., 2020).

The socio-cultural differences of society will have an impact on a person's values and beliefs in comprehending and coping a problem or an issue. For example, in fighting the COVID-19 outbreak, instead of avoiding crowded, people in several districts in Aceh tend to hold on to their religious practices, such as carrying out religious event collectively around the villages - dzikir, that is an Islamic tradition where many people sit together reciting the Holy Quran and praising their prophet Muhammad SAW. People believe that this activity can prevent the spread of the contagious disease (Fahzian, 2020).

Information seeking is a concept related to the process and desire to obtain the desired information from various sources (Kim et al., 2020). In the emergency period of the COVID19 pandemic, information seeking is an important aspect and process to gain correct information on how to prevent the spread of the Coronavirus as well as information about the impact of the global disease. People seek information to reduce the uncertainty caused by the escalation of information about the outbreak. The search for information is related to the information the public wants and needs and the media channels or platforms they use to obtain that information (Kim et al., 2020; Rosemary, 2018).

Several studies examined the relationship between the announcement of the COVID-19 cases and the increased search for information about this pandemic. This condition occurs in several countries, such as the United States (Bento, I et al., 2020), Spain (Moreno, Lara, Fuentes, \& Navarro, 2020), Singapore and South Korea (Kim et al., 2020), including 
Indonesia (Limilia \& Pratamawaty, Bona, 2020). The results of all these studies indicate relatively positive information-seeking behavior about COVID-19 and efforts to acquire information about this pandemic. There has been no study that specifically examines how the community searches for information related to COVID-19 in a collective cultural context, such as the people of Aceh, including studies that identify the media people choose and use in seeking this information, and how they respond to the information obtained.

\section{Material and Methodology}

This study uses a descriptive study through the distribution of online surveys to identify the media use to seek information about COVID-19 and to investigate the response of the Acehnese people to COVID-19 information. This research is not quantitative research with hypothesis testing and does not require a sampling method under the error term. This research questionnaire question was not built with "validity" and "reliability" tests but was built based on research needs.

The data collected through this online survey is the data related to COVID-19 and information seeking which belongs to the Department of Communication Studies, Faculty of Social and Political Sciences, University of Syiah Kuala, and the Center for Innovative Government and Society Studies (CIGSS).

The online survey was conducted amid the COVID-19 pandemic-May and June 2020. The survey was distributed through various media platforms, both SMS and social media, such as WhatsApp, Facebook, Instagram, and Twitter. Respondents were asked for their consents before filling out the survey. The survey questions included respondents' demographic information and questions related to the media used by the public to find information about COVID-19. Respondents were also asked to answer questions about their perceptions and responses to the Coronavirus information received.

The data collected from the online survey are analyzed quantitatively using SPSS tool to measure the percentage value of each analyzed variables. The findings regarding the media used by respondents in seeking information related to COVID-19 and their responses to the information are explained descriptively.

\section{Results and Discussion}

A total of 324 respondents agreed to participate in and fill out an online survey. The survey is about the media use to search information about COVID-19 and the response of the Acehnese people about COVID-19. The number of female respondents $(51.5 \%)$ was more than men $(48.5 \%)$ of various ages. The majority were adolescents, namely 19 years $(13 \%)$, and generally were students, especially non-health students (38.6\%). From their educational backgrounds, the average respondent had graduated from high school $(41 \%)$. Considering that the majority of respondents were students, most of them were single $(66.4 \%)$ and admitted they did not have a regular income $(40.4 \%)$ because they had not worked. Generally, respondents live in urban areas $(65.3 \%)$ and mostly come from Eastern Aceh District (40.4\%).

The different statuses and backgrounds of respondents indicate that women have access to media more than men. These results confirm the findings made by the Pew Research Center on media use, specifically on social media, in 2015. Women tend to use social media more frequently $(68 \%)$ than men $(62 \%)$. The cluster of young people in this study allegedly had a higher response and enthusiasm in seeking information related to the COVID-19 outbreak. The data confirm the findings that the young adult group, namely those aged 18 to 29 years, is the group that uses social media the most, which is around $90 \%$ compared to other age groups (Perrin, 2015).

\section{Media Usage to Seek Information about COVID-19}

Regarding questions on seeking information about COVID-19, the majority of respondents admitted that they often sought (through reading) information about the spread of this virus. This confirms the research conducted by Limlia and Pratamawaty regarding the acceleration search for messages about COVID-19 in Indonesia, especially after the government announces the health emergency (Limilia \& Pratamawaty, Bona, 2020). This intense search for the information is understandable, considering the COVID-19 outbreak is a new issue but has a significant impact on aspects of people's lives, particularly social and economic.

Communities' active behavior in seeking information about COVID-19 shows that respondents prefer to use mass mediaTelevision (TV) to gain information about the pandemic. Our study found that respondents trusted the COVID-19 information conveyed by television media $(36.1 \%)$, followed by online 
media or internet $(32.7 \%)$, and social media $(19.8 \%)$. Although social media is argued as the most frequently used platform by respondents, especially among young people, the Acehnese people are likely to prefer and trust the information about COVID-19 conveyed by the mainstream media, especially TV, as the main source to obtain information about the pandemic.

This condition can be explained, considering that the information conveyed by the mainstream media can also be accessed online (media digitization) and live streaming. This confirms the finding of previous studies on media preference in seeking health information, that female respondents prefer online media. Apart from the fact that the information obtained is quick and can be immediately shared with others, the flexible nature of the media (mobile), which can be accessed anywhere through the screen of a cellular phone (cell phone) (including while traveling), is their choice of entrusting social media to find information about health (Rosemary, 2018).

Trusted Media Platform for Information about COVID-19

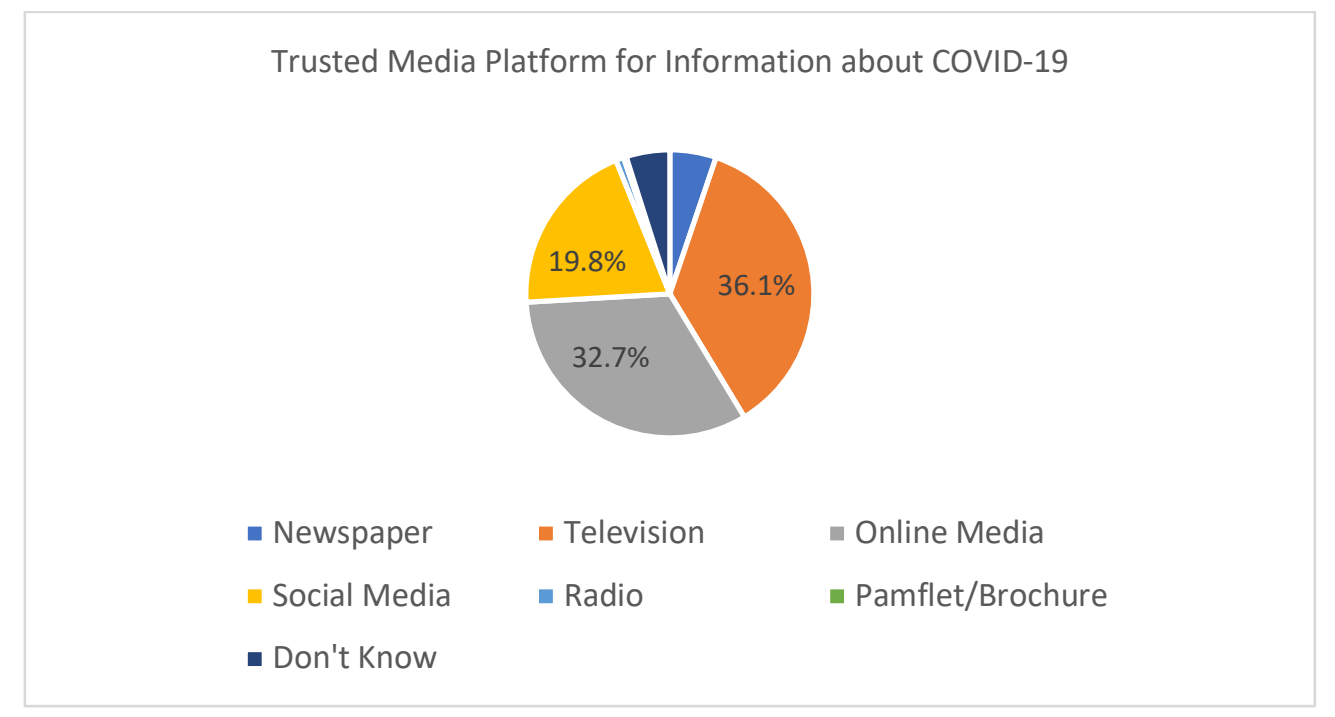

Figure 1. Trusted media platform for information about COVID-19 Source: Statistics Analysis (SPSS)

The findings support the collaborative study conducted by the Faculty of Communication Sciences, Padjajaran University (Unpad), and Pancasila University who are collaborating with the Department of Empirical Media Research and Political Communication Technische, Universtät Ilmenau in Germany. The three educational institutions conducted joint research on public opinion regarding government policies in handling COVID-19. The results of a study presented in the Unpad Public Relations Press Release confirmed that people tend to seek and rely on information about COVID-19 through the mass media, especially private television, compared to health information delivered directly by the central government. The majority of respondents studied (82\%) claimed to receive information about COVID-19 through private TV channels, and 58\% get information through Central TVRI and Regional TVRI broadcasts (West Java Provincial Government, 2020).
This study found that respondents have a high dependency on the media (both mainstream and new media). The results of this online survey also found that respondents trusted information related to COVID-19 from the mass media more than information from health workers or other health experts. These findings are relatively different from a survey conducted by Kantar Sifo - a market research company in Sweden. The audience survey found that the media remains the main source of access to information. The public has higher trust in information about COVID-19 conveyed by health experts and researchers compared to information reported by other sources through national media (Vetenskap \& Allmänhet, 2020).

Differences of belief in the information sought and chosen by the community are influenced by many factors, both individual characteristics, social-economic status, education to the cultural and political context of the local community (Lewis \& Lewis, 2014). In the Indonesian context, there are also concerns 
about how the media tends to overexpress negative things in capturing and disseminating information about COVID-19 which causes people to feel depressed rather than enlightened by the information. This shows the importance of information sources and content to create behavior change in society.

\section{Public Response to COVID-19 Information}

This online survey found variations in people's opinions and responses to the COVID19 information they sought or received. Most respondents argued that the government (both Central and Regional Government) remains a lack of action in disseminating and handling the information about COVID-19. This condition affects their level of trust in the government as the main and official source of information regarding health pandemic.
The survey respondents showed that the government is still relatively slow in providing information related to data on confirmed COVID-19 cases. The COVID-19 data was updated and available through the website of the Ministry of Health of the Republic of Indonesia, namely the Ministry of Health's Emerging Infection page (Kemenkes, 2020). and, for Aceh, it was provided by the Aceh Provincial Health Office through the Aceh Health Service website (Aceh Government, 2020; Aceh Health Department, 2020) However, respondents deemed the available data incomplete and outof-date. This is understandable that not everyone has an interest in numerical information which is difficult for them to understand without further explanation.

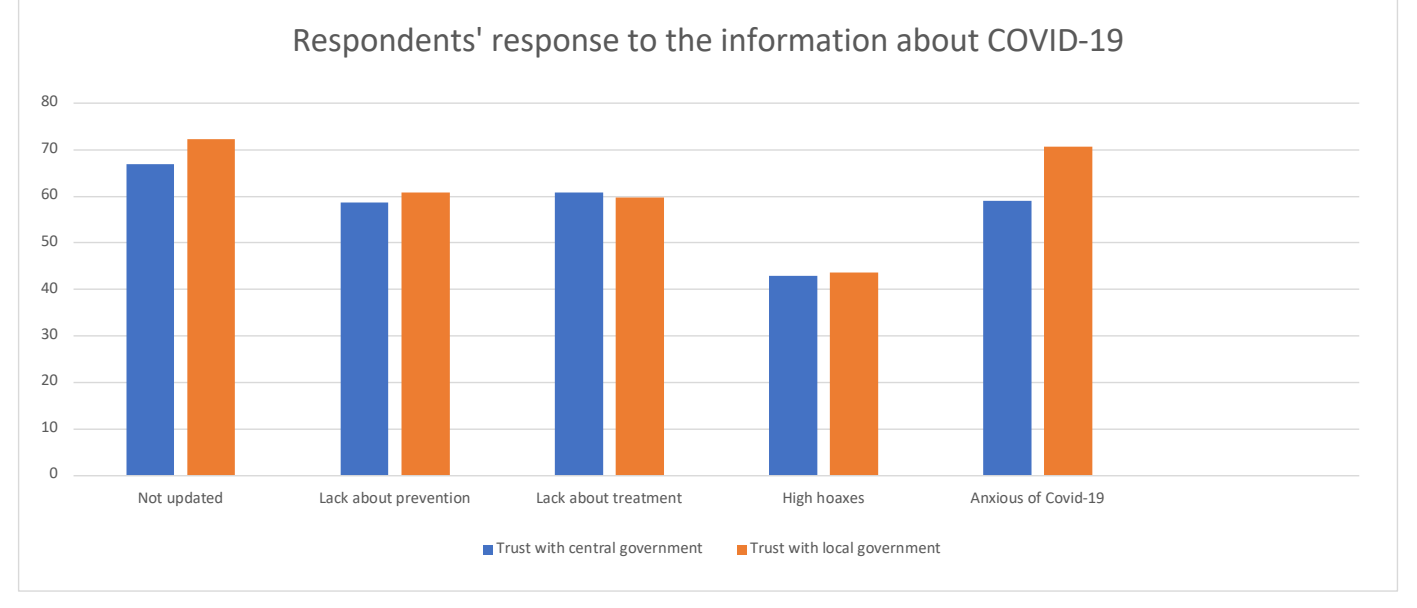

Figure 2. Summary of Respondents' Response to the Information about COVID-19 Source: Statistics Analysis (SPSS)

In addition, respondents considered that the government was still lacking in providing information as to preventing the spread of the Coronavirus and how to treat patients with confirmed COVID-19. The limited information related to these two health aspects, especially in the early days of the pandemic in Aceh, is understandable, given the emergency nature and limited credible sources that can convey one-way official information to the public. However, the vacuum of such information has the potential to generate hoaxes or false information submitted by untrustworthy sources. This condition was confirmed by respondents who stated that there was still a lot of fake information related to COVID-19 which had the opportunity to grow since it was easily and quickly shared and forwarded by the community through social media.

The spread of false information creates confusion and uncertainty in the community, which contributes to the increase in their anxiety and worry about this pandemic condition. As stated by (Jovančević \& Milićević, 2020), (Berawi, Ali, 2020) and (Peconga, $\mathrm{K}$ et al., 2020). When people are anxious, they are likely to be influenced by information that they perceive can secure and protect them in socio-economic, health, and well-being. This type of person tends to entrust information distributed around their circle which has a potential social, economic, and health protection (Nurrahmi \& Syam, 2020; Tasnim, Hossain, \& Mazumder, 2020), particularly within the society having high 
engagement with social media. According to research carried out by the researchers, the widespread use of social media has an implication to the spread of fake news or hoaxes through the social media platforms (Apuke, Destiny \& Omar, 2020; Nurrahmi \& Syam, 2020; Tagliabue, Luca Galassi, \& Mariani, 2020),

The increase in death cases due to COVID19 is spreading rapidly around the world, including in Indonesia, and Aceh. This false information about the global pandemic results in people's feelings of worry, anxiety, and even stress. Many Acehnese people are feeling anxious, panic, and uncertain. This condition made them vulnerable to hoaxes about the outbreak. For example, information about drinking infused water can protect from the Coronavirus, or the COVID-19 involves a conspiration issue.

The spread of information about COVID19 in the community which is sometimes difficult to differentiate between accurate and false information (hoaxes) is problematic, especially when people are reluctant and ignore the importance of information checking before consuming the messages. The information overload on the health issue causes psychological problems, such as anxiety and uncertainty. According to Nicomedes \& Avila (2020) Nguyen \& Vu (2020), and Ahinkorah et al. (2020), anxiety is a response to certain threatening situations and is a normal condition that occurs because of the impact of development, changes, and new experiences. Anxiety is characterized by the appearance of fear, caution, and vigilance that is unclear and unpleasant. Anxiety mostly occurs when information received is not clear, and sometimes false/fake (hoax) and inadequate. The normal feeling of anxiety then becomes abnormal anxiety as experienced by individuals and people.

The overload of information (tsunami information) addressing COVID-19, particularly fake information, tends to attract people's attention because some of the messages convey the idea of protection to people's socio-economic, and health likelihood. People prefer and neglect the information that is not benefitting them. The unavoidable massive information results in people becoming more anxious because of their inability to filter the accurate and important information over those that are false and unnecessary.

\section{Conclusion}

This study provides information on how people in Aceh seek information related to COVID-19 through the media they use to find this information and their responses to the information received. Respondents use more online media in addition to other mass media, such as TV, in obtaining information about this pandemic. People have higher trust in the information conveyed by the media than the information distributed directly (face-to-face) from the government including experts and health workers and members of the Aceh Province COVID-19 Task Force.

The public's high dependence on the media makes them vulnerable to receiving false information about this issue, which they should have obtained through accurate sources made available officially by the government. Their vulnerability to various false information (hoaxes) affects their responses to the information they receive. This study found that respondents had a negative response to the information released by the government, especially regarding actions in handling COVID-19 in Aceh province. The low level of public trust in the actions and policies taken by the government in overcoming the COVID-19 health emergency influences how people react to this pandemic.

This study only explores people's information-seeking behavior regarding COVID-19 information through the media they use. The limitation of this study is merely explaining the types of media platforms used by respondents in seeking information, that affect what information they get, which can be seen from their responses to the information received. Further studies are needed to discover more about the impact of the information received on people's attitudes and behaviors about the pandemic, specifically how the community attitudes and behaviors regarding the health protocol information and their compliance with the regulation to prevent and stop the spread of the Coronavirus.

\section{Acknowledgements}

This paper derives from research carried out by the Department of Communication Studies, Faculty of Social and Political Sciences, Syiah Kuala University and the Center for Innovative Government and Society Studies (CIGSS). The authors are indebted to 
the research respondents who participated in this study.

\section{References}

Abrams, M, E., \& Matthew, G. (2020). Risk Communication During COVID-19. The Journal of Allergy and Clinical Immunology: In Practice, 8(6), 17911794.

https://doi.org/https://doi.org/10.1016/j.jai p.2020.04.012

Aceh Government. (2020). Aceh Tanggap COVID-19.

Aceh Health Department. (2020). Data COVID-19 Aceh.

Afifah, Nur, M. (2020). Bagaimana Dampak Stres Pandemi Corona pada Kesehatan Mental dan Fisik? Kompas.Com.

Ahinkorah, Opoku, B., Ameyaw, Kwabena, E., Hagan, Elvis, J., Seidu, A.-A., \& Schack, T. (2020). Rising Above Misinformation or Fake News in Africa: Another Strategy to Control COVID-19 Spread. Frontiers in Communication, 5(June), 2018-2021. https://doi.org/10.3389/fcomm.2020.0004 5

Apuke, Destiny, O., \& Omar, B. (2020). Fake news and COVID-19: modelling the predictors of fake news sharing among social media users. Elsevier Public Health Emergency Collection, 56(101475). https://doi.org/10.1016/j.tele.2020.101475

Atkin, C. (1972). Anticipated Communication And Mass Media Information-Seeking. Public Opinion Quarterly, 36(2), 188-199. https://doi.org/https://doi.org/10.1086/267 991

Bakri. (2020). Kasus COVID-19 di Aceh Melonjak, Sehari 22 Orang Positif. Aceh.Tribunnews.Com.

Bento, I, A., Nguyen, T., Wing, C., LozanoRojas, F., Ahn, Yong, Y., \& Simon, K. (2020). Evidence from internet search data shows information-seeking responses to news of local COVID-19 cases. In P. Milgrom, R (Ed.), Proceedings of the National Academy of Sciences of the United States of America (Vol. 117, pp. 11220-11222). USA: PNAS. https://doi.org/10.1073/pnas.2005335117

Berawi, Ali, M. (2020). Empowering Healthcare, Economic, and Social Resilience during Global Pandemic COVID-19. International Journal of Technology (IJTech), 11(3436-439). https://doi.org/https://doi.org/10.14716/ijt ech.v11i3.4200
Budiansyah, A. (2020, March 17). Ramai Work From Home, 10 Aplikasi Ini Bantu Tetap Produktif. Www.Cnbcindonesia.Com.

Covello, T, V., Peters, G, R., Wojtecki, G, J., \& Hyde, C, R. (2001). Risk communication, the West Nile virus epidemic, and bioterrorism: Responding to the communication challenges posed by the intentional or unintentional release of a pathogen in an urban setting. Journal of Urban Health, 78(2), 382-391. https://doi.org/10.1093/jurban/78.2.382

Dinamika, Y. (2020). Bertambah 168 Orang Positif Corona di Aceh, Masuk Tiga Besar Nasional. Aceh.Tribunnews.Com.

Eda, F. (2020). Juru Bicara COVID-19 Achmad Yurianto Apresiasi Cara Aceh Tekan Penyebaran Virus Corona. Aceh.Tribunnews.Com.

Evensen, D. T., \& Clarke, C. E. (2012). Efficacy Information in Media Coverage of Infectious Disease Risks: An Ill Predicament? Science Communication, 34(3), 392-418. https://doi.org/https://doi.org/10.1177/107 5547011421020

Fahzian, A. (2020, March 24). Cara Orang Aceh Terdahulu Mengusir Wabah Penyakit. Tagar.Id.

Feldman, L., Hart, Sol, P., \& Milosevic, T. (2015). Polarizing news? Representations of threat and efficacy in leading US newspapers' coverage of climate change. Public Understanding of Science, 26(4), 481-497.

https://doi.org/doi.org/10.1177/09636625 15595348

Frewer, L. (2004). The public and effective risk communication. Toxicology Letters, 149(1-3), 391-397. https://doi.org/https://doi.org/10.1016/j.to xlet.2003.12.049

Joanna, Ching-Sei, S., I-Tien, T., \& SunKyung, K. (2014). Individual differences in social media use for information seeking. Journal of Academic Librarianship, $\quad 40(2), \quad$ 171-178. https://doi.org/10.1016/j.acalib.2014.03.0 01

Jovančević, A., \& Milićević, N. (2020). Optimism-pessimism, conspiracy theories and general trust as factors contributing to COVID-19 related behavior - A crosscultural study. Elsevier Public Health Emergency Collection, 167(110216). https://doi.org/10.1016/j.paid.2020.11021 6 
Kemenkes. (2020). Data COVID-19 Indonesia. Kim, Sun, K., Sin, Joanna, Ching, S., \& He, Y. (2013). Information Seeking through Social Media: Impact of User Characteristics on Social Media Use. In Proceedings of the ASIST Annual Meeting (Vol. 50, pp. 1-4). Montreal, Quebec, Canada: Asist. https://doi.org/10.1002/meet.1450500115 5

Kim, H. K., Ahn, J., Atkinson, L., \& Kahlor, L. A. (2020). Effects of COVID-19 Misinformation on Information Seeking, Avoidance, and Processing: A Multicountry Comparative Study. Science Communication, 42(5), 586-615. https://doi.org/10.1177/107554702095967 0

Lewis, B., \& Lewis, J. (2014). Health Communication: A Media and Cultural Studies Approach. London: Palgrave Macmillan. https://doi.org/10.1007/978/1-137-47864-1

Limilia, P., \& Pratamawaty, Bona, B. (2020). Google Trends and Information Seeking Trend of COVID-19 in Indonesia. Jurnal ASPIKOM, 5(2), 188-205. https://doi.org/10.24329/aspikom.v5i2.74 1

Moreno, Á., Lara, Fuentes, C., \& Navarro, C. (2020). COVID-19 communication management in Spain: Exploring the effect of information-seeking behavior and message reception in public's evaluation. Profesional de La Informacion, 29(4), 116. https://doi.org/10.3145/epi.2020.jul.02

Muusses, L. D., Weert, van, J. C. M., \& Dulmen, van, S. (2011). Chemotherapy and information-seeking behaviour: characteristics of patients using massmedia information sources. Psycho Oncology, 21(9), 993-1002. https://doi.org/https://doi.org/10.1002/pon .1997

Ngadi, N., Meliana, R., \& Purba, Y. A. (2020). Dampak Pandemi COVID-19 Terhadap Phk Dan Pendapatan Pekerja Di Indonesia. Jurnal Kependudukan Indonesia, 2902, 43. https://doi.org/10.14203/jki.v0i0.576

Nguyen, H.D, T., \& Vu, C, D. (2020). Impacts of the COVID-19 Pandemic Upon Mental Health: Perspectives From Vietnam. Psychological Trauma: Theory, Research, Practice, and Policy, 12(5), 480-481. https://doi.org/10.1037/tra0000694

Nicomedes, Jasper C, C., \& Avila, R. M. A. (2020). An analysis on the panic during
COVID-19 pandemic through an online form. Elsevier Public Health Emergency Collection, 1(276), 14-22. https://doi.org/10.1016/j.jad.2020.06.046

Nurrahmi, F., \& Syam, H. M. (2020). Perilaku Informasi Mahasiswa dan Hoaks di Media Sosial. Communicatus: Jurnal Ilmu Komunikasi, 4(2), 129-146. https://doi.org/10.15575/cjik.v4i2.9215

Peconga, K, E., Gauthier, M, G., Holloway, A., Walker, S.W, R., Rosencrans , L, P., Zoellner, A, L., \& Gilligan, Bedard, M. (2020). Resilience Is Spreading: Mental Health Within the COVID-19 Pandemic. Psychological Trauma: Theory, Research, Practice, and Policy, 12(S1. S47-S48), 47-48. https://doi.org/10.1037/tra0000874

Perrin, A. (2015). Social Media Usage: 20052015. American.

Putri, N. E., Hakim, N., \& Yamin, M. (2016). Ecologicall Footprint and Biocapacity Analysis for Flooding Prevention in South Sumatera. Jurnal Mimbar, 32(1), 58-64.

Rosemary, R. (2018). Pilihan Media Pencari Informasi Kesehatan. Jurnal Komunikasi Global, $\quad 7(2), \quad$ 169-182. https://doi.org/10.24815/jkg.v7i2.11756

Rosemary, R., \& Evensen, D. (2020). Unveiling the 'Green': Media Coverage on the Aceh Green Vision, Indonesia. In A. E. Djalante R., Jupesta J. (Ed.), Climate Change Research, Policy and Actions in Indonesia (pp. 281-300). Switzerland: Springer, Cham.

https://doi.org/https://doi.org/10.1007/978 -3-030-55536-8 14

Supriatin, T. (2020). Cara Aceh Tekan Penyebaran Kasus Corona COVID-19. Www.Liputan6.Com.

Tagliabue, F., Luca Galassi, \& Mariani, P. (2020). The "Pandemic" of Disinformation in COVID-19. SN Comprehensive Clinical Medicine, 2(1287-1289). https://doi.org/https://doi.org/10.1007/s42 399-020-00439-1

Tasnim, S., Hossain, M., \& Mazumder, H. (2020). Impact of rumors and misinformation on COVID-19 in Social Media. Journal of Preventive Medicine and Public Health, 53(3), 171-174. https://doi.org/10.3961/JPMPH.20.094

Vetenskap, \& Allmänhet. (2020). Coronavirus In The Swedish Media Study - High Public Confidence In Researchers And Healthcare Professionals.

West Java Provincial Government. (2020). Masyarakat Aktif Mencari Informasi 
COVID-19.

Wilson, T. . (1999). Models In Information

Behaviour
Research.
$55(3)$

243-244. https://doi.org/http://dx.doi.org/10.1108/EUM0 000000007145 